\title{
Cytocompatibility and Mechanical Strength of Hydroxyapatite Reinforced with Multi-Walled Carbon Nanotubes
}

\section{Sharif Hussein Sharif Zein* and Fatemeh Gholami}

School of Chemical Engineering, Engineering Campus, University Sains Malaysia, Seri Ampangan, 14300 Nibong Tebal, Pulau Pinang, Malaysia

Hydroxyapatite $\left(\mathrm{HA}, \mathrm{Ca}_{10}\left(\mathrm{PO}_{4}\right)_{6}(\mathrm{OH})_{2}\right)$ composition is similar to the mineral phase of bone and is an excellent material to use in bone replacement materials. Clinically, it has been used in dental and orthopaedic applications in bulk form as filler, and as a coating for more than 30 years [1]. However, its poor mechanical properties (natural brittleness and unsatisfactory strength of HA) prevented it from being used in clinical applications, under load-bearing [2].

Since carbon nanotubes (CNTs) entered the world materials stage [3], their mechanical properties have been praised as some of the best present. CNTs possess outstanding mechanical properties and chemical stability which resulted from their cylindrical graphitic structure, and carbon is one of the known fundamental basics in the development of life on the planet Earth [4]. Their strength and stiffness, combined with their small size and large interfacial area suggest they may have great potential as reinforcing agent for HA [5]. Thus, HA composite coatings reinforced with CNTs might have tailored properties, including high strength and good bioactivity [6]. In order to obtain an acceptable mechanical reinforcement, the surface of CNTs must be functionalized to improve the dispersion of individual CNTs in the ceramic matrix, and also to induce perfect interfacial bonding between CNTs and HA, which could be ultimately responsible for an efficient load-transfer mechanism $[7,8]$.

In the case of CNT-based biomaterials, particular nano toxicity issues must be considered. Recent reviews highlighting nano toxicological challenges with CNTs are available [9-11]. If CNTs are to be included into composite substances for medical applications, evidence of their potential bioactivity and toxicity is necessary. Depending on the dissolution rate of the matrix material in vivo, CNTs could be released into the body, possibly inducing a harmful response. The presence of CNTs may have no damaging effects and could even enhance its bioactive properties. The response of multi-walled carbon nanotubes (MWCNTs) to human lung epithelial cells, osteoblast-like cells and primary osteoblast cells showed that these cells attached and survived on MWCNTs, although the proliferation effect is not much. They suggested that the dimensions and spacing of CNTs may be the key to determine subsequent cell spreading and proliferation [12]. Other studies have shown that functionalising CNTs can improve their aqueous dispersibility and biocompatibility [13-15]. The aim of this study is to investigate the mechanical properties and the cytotoxicity of the HA composites, incorporated with different types of MWCNTs.

The cytotoxicity and mechanical properties of a novel multi-walled carbon nanotube reinforced hydroxyapatite composite, using different types of MWCNTs (MWCNTs, 95\% purity, MWCNTs-OH, 99.9\% purity) are presented. Compressive strength tests and cell culture experiments with human CCD-18Co fibroblasts were performed. Briefly, HA powder was mixed with de-ionized water, 15 wt.\% bovine serum albumin (BSA) and 0.5 wt.\% of hydroxylated MWCNTs (MWCNTs-OH, purity 99.9\%), MWCNTs (MWCNTs, purity 99.9\%) and MWCNTs (MWCNTs, purity 95\%), respectively, to produce HA/ MWCNTs-OH/BSA and HA/MWCNTs/BSA composites. The paste was packed into a cylindrical stainless steel mold (diameter $=6 \mathrm{~mm}$, length $=12 \mathrm{~mm}$ ), and stored in a Gyro-Rocker Incubator (Model: S170) at $37^{\circ} \mathrm{C}$ and $97 \%$ humidity for $24 \mathrm{~h}$. Then, the samples were taken out and dried at room temperature. Viability of human fibroblast cells (CCD-18Co) was assessed using the MTT assay. To test the cytocompatibility of the HA/MWCNT/BSA samples which is in powder form (to increase the surface area of the particles, in order to cover the cells completely), the viabilities of the cells were determined. CCD-18co cells were seeded at a density of $1.5 \times 10^{5}$ cells per well in 96-well plates. The test substance was diluted with media to the desired concentrations of $6.25,12.5,25,50,100$ and $200 \mu \mathrm{g} / \mathrm{ml}$ from the stock. Into each well containing the cells, $100 \mu \mathrm{l}$ of test substance of various concentrations was added, and $100 \mu \mathrm{l}$ of medium (as the control) was added to the cells. The mitochondrial respiratory activity of the fibroblasts treated with the composite was determined colorimetrically, using MTT assays [16].

Figure 1 shows the effect of HA composites on CCD-18Co fibroblast cells, as measured by MTT assay. Cytotoxicity study indicates that in low concentrations of tested samples, both composites show better biological response in promoting cell growth compared to higher concentrations. However, according to the results, HA/ MWCNT-OH/BSA composites were not only non-toxic in different concentrations between $6.25-200 \mu \mathrm{g} / \mathrm{ml}$, but also at low concentration $(6.25 \mu \mathrm{g} / \mathrm{ml})$ of test samples, it indicated a proliferative effect on CCD18 Co cells. As shown in figure 1 , at low concentrations $(6.25 \mu \mathrm{g} / \mathrm{ml})$, HA/MWCNT-OH/BSA showed approximately $200 \%$ cell viability; thus, this composite had a greater effect on the viability of the cells. All quantitative data are expressed as mean \pm deviation, and the level of statistical significance was defined as $\mathrm{p}<0.05$.

In the last study [17], cytotoxicity of calcium phosphate composite (CPC/MWCNT-OH/BSA) was studied. The percentage of CCD18 Co cell viability was reduced from $102 \%$ to $66 \%$, by increasing the concentration from $6.25-200 \mu \mathrm{g} / \mathrm{ml}$. Figure 2 shows the effect of CPC/MWCNT-OH/BSA and HA/MWCNT-OH/BSA composites on viability of CCD-18Co cells. It indicates that a cell proliferative effect of the HA/MWCNT-OH/BSA composites is significantly higher than the $\mathrm{CPC} / \mathrm{MWCNT}-\mathrm{OH} / \mathrm{BSA}$ composite, especially in a low concentration of $6.25 \mu \mathrm{g} / \mathrm{ml}$.

*Corresponding author: Sharif Hussein Sharif Zein, School of Chemical Engineering, Engineering Campus, University Sains Malaysia, Seri Ampangan 14300 Nibong Tebal, Pulau, Pinang, Malaysia, Tel: +604-599-6442; Fax: 604-5941013; E-mail: chhussein@eng.usm.my

Received October 29, 2012; Accepted October 30, 2012; Published November 02, 2012

Citation: Sharif Zein SH, Gholami F (2012) Cytocompatibility and Mechanical Strength of Hydroxyapatite Reinforced with Multi-Walled Carbon Nanotubes. J Bioengineer \& Biomedical Sci 2:e111. doi:10.4172/2155-9538.1000e111

Copyright: ( 2012 Sharif Zein SH, et al. This is an open-access article distributed under the terms of the Creative Commons Attribution License, which permits unrestricted use, distribution, and reproduction in any medium, provided the original author and source are credited. 
Citation: Sharif Zein SH, Gholami F (2012) Cytocompatibility and Mechanical Strength of Hydroxyapatite Reinforced with Multi-Walled Carbon Nanotubes. J Bioengineer \& Biomedical Sci 2:e111. doi:10.4172/2155-9538.1000e111

Page 2 of 2

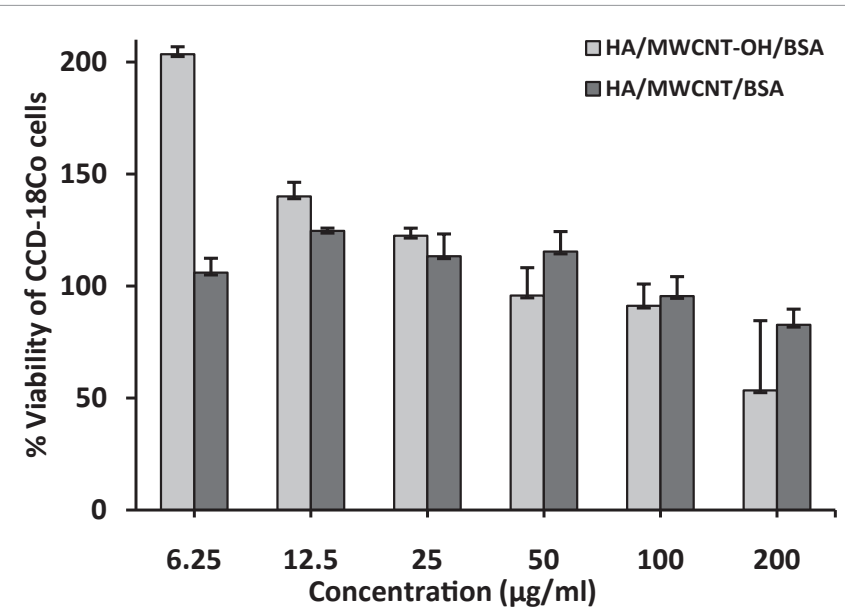

Figure 1: Effect of HA composites on CCD-18Co fibroblast cells as measured by MTT assay. (Data are presented as the means \pm 2 standard deviations, $n$ $=3$ ).

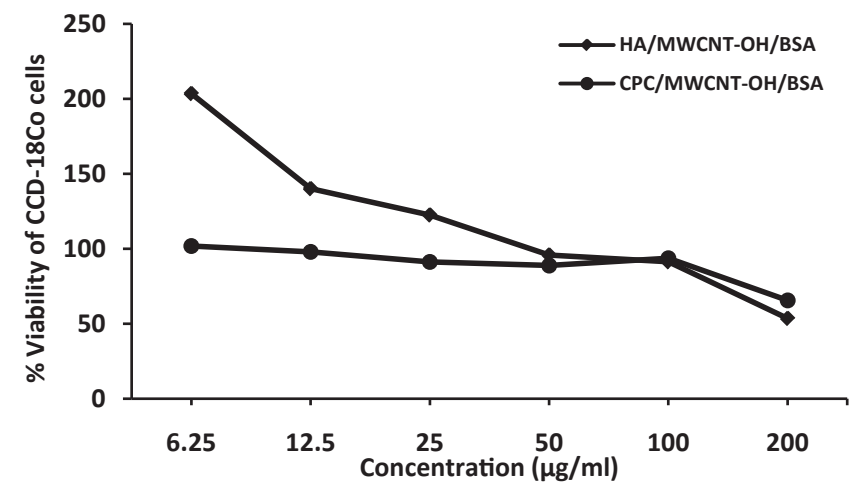

Figure 2: Effect of CPC/MWCNT-OH/BSA and HA/MWCNT-OH/BSA composites on viability of CCD-18Co cells (Data are presented as the means \pm 2 standard deviations, $n=3$ ).

The compressive strength of composites was tested using an Instron 3367 universal testing machine, with crosshead speed of $1.0 \mathrm{~mm} / \mathrm{min}$. Results showed that the HA/MWCNT-OH/BSA composite had higher compressive strength $(20 \mathrm{MPa})$, compared to HA/MWCNT/BSA with compressive strength of $13 \mathrm{MPa}$. Compressive strength of trabecular bone is in the range of 2-12 $\mathrm{MPa}$, and for cortical bone it is in the range of 100-230 MPa. The compressive strength of new composite is in the range of cortical and trabecular bone, thus, it has potential for being used as the bone replacement material.

In this study, HA/MWCNT/BSA composites prepared with various types of MWCNT (MWCNT-OH, 99.9\% purity and MWCNT with 95\% purity). The novel HA/MWCNT-OH/BSA composites showed favourable cytocompatibility with high compressive strength (20 $\mathrm{MPa}$ ), and it is therefore, considered an attractive bone replacement material. The biological effect of the compound in cell proliferation hints potential wound healing effect, which adds further benefit to this composite. Further studies are required to find the mechanism of affecting cells by these composites, and more research is needed for increasing the compressive strength of composite to make it applicable in clinical purpose, under load-bearing.

\section{References}

1. Suchanek W, Yoshimura M (1998) Processing and properties of hydroxyapatite based Biomaterials for use as hard tissue replacement implants. J Mater Res 13: 94-117.

2. Qiu D, Yang L, Yin Y, Wang A (2011) Preparation and characterization of hydroxyapatite/titania composite coating on $\mathrm{NiTi}$ alloy by electrochemical deposition. Surf Coat Technol 205: 3280-3284.

3. lijima S (1991) Helical microtubules of graphitic carbon. Nature 354: 56-58.

4. Cheng HM (2002) Synthesis, microstructure, properties and applications of carbon nanotubes. Beijing: Chemistry Press 4.

5. Gojny FH, Nastalczyk J, Roslaniec Z, Schulte K (2003) Surface Modified MultiWalled Carbon Nanotubes in CNT/Epoxy-Composites. Chem Phys Lett 370: 820-824.

6. Elghazal H, Lormand G, Hamel A, Girodin D, Vincent A (2000) Microplasticity characteristics obtained through nano-indentation measurements: application to surface hardened steels. Mater Sci Eng A 303: 110-119.

7. White AA, Best SM, Kinloch IA (2007) Hydroxyapatite-carbon nanotube composites for biomedical applications: a review. International Journal of Applied Ceramic Technology 4: 1-13.

8. Boccaccini AR, Gerhardt LC (2010) Carbon nanotube composite scaffolds and coatings for tissue engineering applications. Key Eng Mater 441: 31-52.

9. Aschberger K, Johnston HJ, Stone V, Aitken RJ, Tran CL, et al. (2010) Review of fullerene toxicity and exposure--Appraisal of a human health risk assessment based on open literature. Regul Toxicol Pharmacol 58: 455-473.

10. Diot P, Pairon JC, Boczkowski J, Guillot-Gautier M, Glas N (2010) The respiratory effects of inhaling nanoparticles. Revue des Maladies Respiratoires Actualités 2: 365-367.

11. Thurnherr T, Brandenberger C, Fischer K, Diener L, Manser P, et al. (2011) A comparison of acute and long-term effects of industrial multiwalled carbon nanotubes on human lung and immune cells in vitro. Toxicol Lett 200: 176-186.

12. George JH, MS Shaffer, MM Stevens (2006) Investigating the cellular response to nanofibrous materials by use of a multi-walled carbon nanotube model. Journal of Experimental Nanoscience 1: 1-12.

13. Pantarotto D, Briand JP, Prato M, Bianco A (2004) Translocation of bioactive peptides across cell membranes by carbon nanotubes. Chem Commun (Camb) 16-17.

14. Sayes CM, Fortner JD, Guo W, Lyon D, Boyd AM., et al. (2004) The differential cytotoxicity of water-soluble fullerenes. Nano Lett 4: 1881-1887.

15. Sayes CM, Liang F, Hudson JL, Mendez J, Guo W, et al. (2006) Functionalization density dependence of single-walled carbon nanotubes cytotoxicity in vitro. Toxicol Lett 161: 135-142.

16. Mosmann T (1983) Rapid colorimetric assay for cellular growth and survival: application to proliferation and cytotoxicity assays. J Immunol Methods 65: 5563.

17. Zein SHS (2011) Cytotoxic Properties of Calcium Phosphate/Multi-walled Carbon Nanotubes/Bovine Serum Albumin on the CCD-18Co cell line. J Tissue Sci Eng 2: e107. 